\title{
Żydowska Koncepcja Przymierza w ujęciu Maxa Webera
}

Max Weber dowodził, że przymierze stanowiło element procesu racjonalizacji religii starożytnych Izraelitów oraz że w sferę religijną przeniesione zostało jako praktykowane od dawna narzędzie regulacji stosunków społecznych w celu nadania tym relacjom stabilności. Dla tej tezy Webera, jak i całej jego wnikliwej analizy historii starożytnego Izraela, punktem wyjścia była niemiecka tradycja „wyższej krytyki” biblijnej, zwłaszcza ustalenia Juliusa Wellhausena. Weber stał się obserwatorem, ale i uczestnikiem narastających uprzedzeń wobec Żydów. Stąd też jego określenie „naród pariasów” i aprobata krytycznego nastawienia Friedricha W. Nietzschego, określającego Żydów jako twórców etyki niewolniczej. Tłem dla analizy biblijnych dziejów Izraelitów były dla Webera ustalenia Juliusa Wellhausena, wypada zatem poświęcić im nieco uwagi, zanim przejdziemy do rozważań samego Webera.

\section{Przymierze w ujęciu Juliusa Wellhausena}

W 1878 roku Wellhausen opublikował Geschichte Israels (vol. I, Berlin 1878, w drugim wydaniu i następnych tytuł został zmieniony na Prolegomena zur Geschichte Israels), w której zawarta została teza, że Tora stanowiła ostatni etap w rozwoju izraelickiej religijności. Nie była zatem punktem wyjścia dla historii starożytnego Izraela, ale dla historii judaizmu, będącego przedłużeniem

* Doktor habilitowany, Uniwersytet Łódzki, Wydział Studiów Międzynarodowych i Politologicznych, Katedra Teorii Polityki i Myśli Politycznej. 
skostniałej już wówczas religii, opartej na przepisach kapłańskich. Według Wellhausena wydarzenia synajskie i uznanie Pięcioksiągu jako konstytucji Mojżeszowej były dziełem literatów z V wieku przed Chrystusem. Teza ta spotkała się z uznaniem znawców tematu w Niemczech, którzy do tej pory z dystansem traktowali hipotezę Grafa, według której Deuteronomium i połączone ze sobą części Pięcioksięgu nie zostały napisane przed upadkiem królestwa Judy. Wcześniej krytyką historyczną Biblii hebrajskiej zajmował się teolog z Uniwersytetu w Lejdzie - Abraham Kuenen (1828-1891) (Historisch-kritisch onderzoek naar het onstaan en de verzameling van de boeken des Ouden Verbonds, t. 1-3, 1861-1865; drugie wydanie ukazało się w latach 1885-1893) ${ }^{1}$. Od 1878 roku, po części pod wpływem rosnącego wpływu Kuenena, ale głównie za sprawą pracy Wellhausena, zatriumfowało krytyczne podejście do Pięcio$\mathrm{księgu}^{2}$.

Według Wellhausena pisana historia Izraelitów zaczęła się dopiero około 1000 roku p.n.e., wcześniej świadomość istnienia Boga i jego praw wyrażała się w tradycji i niepisanych prawach zwyczajowych ${ }^{3}$. Różne rodzaje boskich nakazów były zapewne znane patriarchom na długo przed Mojżeszem, ale nie miały one formy pozytywnych przykazań ${ }^{4}$. Pięcioksiąg Mojżeszowy (Tora) - zdaniem Wellhausena - powstawał stopniowo w wyniku kapłańskiej praktyki rozpoznawania wykroczeń i wskazywania odpowiednich zadośćuczynień, i nie nosił początkowo takiej nazwy. Tego rodzaju działalność uległa wzmocnieniu zwłaszcza za czasów monarchii, przyczyniła się do rozwoju prawa cywilnego i uprawnień osoby (ius) jako odrębnej dziedziny z dawnego prawa sakralnego $(f a s)^{5}$. Poprzez swoje nauczanie kapłani stali się filarami nie tylko porządku religijnego, ich wskazówki miały również znaczenie polityczne, pomagały zrozumieć klęski polityczne. Za założyciela i fundatora stworzonej przez siebie tradycji kapłani uznali Mojżesza ${ }^{6}$. Istotne znaczenie dla rozwoju żydowskiej religijności mieli prorocy, traktowani jako kontynuatorzy roli pełnionej przez Mojżesza (interpretacja Prawa), uważani za narzędzia działania ducha Jahwe. Ich głos stawał się szczególnie słyszalny w momentach, gdy istniała szczególna potrzeba przestrzegania stworzonego przez kapłanów Prawa ${ }^{7}$. Tora, zwana też

\footnotetext{
W. Robertson Smith, Preface, [w:] J. Wellhausen, Prolegomena to the History of Ancient Israel, Cleveland, 1957, s. V.

2 Ibidem, s. V-VI.

3 J. Wellhausen, Prolegomena to the History..., s. 393.

4 Ibidem, s. 394.

5 Ibidem, s. 394-395.

6 Ibidem, s. 396-397.

7 Ibidem, s. 399.
} 
mishpat, czyli sądzenie, sprawiedliwość, była przedstawiana przez proroków jako boski, niezniszczalny element Izraela ${ }^{8}$.

Początkiem w dziele budowania Pięcioksięgu było Deuteronomium. Za panowania króla Jozjasza (621 p.n.e.) (2 Krl 22:23) znaleziona została w świątyni „księga Prawa” (2 Krl 22:8), ogłoszona jako Księga Powtórzonego Prawa. Odkrycie to nabrało znaczenia podczas wygnania babilońskiego, zyskując status religijnego osiągnięcia przeszłości, do którego nawiązywano jako do niezniszczalnego drogowskazu w życiu świeckim i religijnym. Zdaniem Wellhausena wraz z umocnieniem znaczenia Deuteronomium ograniczeniu uległa wolność, nie tylko w sferze kultu, skoncentrowanego teraz w Jerozolimie, ale również $\mathrm{w}$ sferze ducha religijnego ${ }^{10}$.

Legislacyjny element Pentateuchu - Kodeks Kapłański (P), nazwany tak przez Wellhausena, określony został jako Prawo Mojżeszowe. Człowiekiem, któremu Pięcioksiąg zawdzięczał swój konstytucyjny status judaizmu, był kapłan i skryba Ezdrasz, przybyły z Babilonu do Jerozolimy w 458 roku p.n.e. ${ }^{11}$ Kodeks Kapłański stanowił podstawę reformy religijnej Ezdrasza i Nehemiasza ${ }^{12}$.

Deuteronomium (D) stało się znane pod koniec VII wieku, a część Tory, zwana Kodeksem Kapłańskim (P) - w drugiej połowie V wieku p.n.e. Deuteronomium było zatem pierwszym, a kapłańska Tora drugim stopniem biblijnej legislacji. Ezdrasz i Nehemiasz oraz mężowie tworzący Wielkie Zgromadzenie (hebr. Knesset Ha Gedolah), znani jako sygnatariusze przymierza, uznani zostali przez późniejszą tradycję za założycieli kanonu. Deuteronomium, a następnie cały Pentateuch, stały się decydującym krokiem, dzięki któremu słowo pisane zastąpiło tradycję ustną, a Izraelici zyskali status ludzi księgi. Pojęcie kanonu odnosi się wyłącznie do Tory pisanej. Spuścizna proroków i hagiografów była również przez Żydów określana jako Tora, jednak nie jako Tora Mojżeszowa (pisana) ${ }^{13}$. Tora pisana stanowi kanon, odróżniający judaizm od starożytnego Izraela ${ }^{14}$.

Początkowo w starożytnym Izraelu prawo boże nie miało charakteru pisanego, a tym bardziej zinstytucjonalizowanego, lecz - jak wierzono - działało w jednostkach jako duch boży. Ówcześni Izraelici działali i mówili pod wpływem impulsu, zgodnie $\mathrm{z}$ duchem Jahwe, nie licząc się z zewnętrznymi normami ${ }^{15}$.

\footnotetext{
Ibidem, s. 400.

Ibidem, s. 402.

10 Ibidem.

11 Ibidem, s. 405.

12 Ibidem, s. 406-407.

13 Ibidem, s. 409.

14 Ibidem, s. 410.

15 Ibidem, s. 412.
} 
Relacja Jahwe i Izraela miała charakter naturalny. Dopiero, gdy istnienie Izraela uznano za zagrożone, zwłaszcza ze strony Asyryjczyków, prorocy, tacy jak Eliasz i Amos, zaczęli głosić koncepcje, w których zrywali z dotychczasowym naturalnym pojmowaniem relacji ludu $\mathrm{z}$ Jahwe, $w$ jej miejsce wykreowali relację zależną od warunków o charakterze moralnym. Jahwe był dla nich w pierwszej kolejności Bogiem sprawiedliwości, dopiero w drugiej - Bogiem Izraela i o tyle, o ile Izrael przestrzegał sprawiedliwych żądań, przezeń objawionych ${ }^{16}$. W ten sposób naturalna dotychczas relacja uzależniona została od spełnienia warunków i tym samym powstała substancja dla czegoś nowego - dla pojęcia przymierza. Nazwa berith nie występuje jednak u dawnych proroków, nawet u Ozeasza, który najbardziej wyraźnie jak to możliwe, daje surogat tego pojęcia w postaci małżeństwa Jahwe i Izraela (Oz 2:4-15; Iz 1:21) ${ }^{17}$.

Wellhausen dowodził, że starożytni Hebrajczycy nie znali innego rozumienia prawa, jak tylko w formie traktatu. Prawo zyskiwało swoją moc wyłącznie w wyniku przyzwolenia tych, których miało dotyczyć, inaczej mówiąc, poprzez fakt, że ci, którym zostało ono dane, zobowiązywali się go przestrzegać (Wj 24:3-8; $2 \mathrm{Krl}$ 23:1-3). Berith harmonizowało z ideą proroków w VIII wieku p.n.e., otrzymało $\mathrm{z}$ ich strony interpretację, według której relacja Jahwe z Izraelem warunkowana była spełnieniem żądań jego sprawiedliwości ${ }^{18}$. Formułę przymierza jednoczącego Izraelitów w wierności Bogu wypracowano w ramach ruchu deuteronomicznego w VII wieku p.n.e. Część prawną przymierza, wyznaczającą obowiązki ludu wobec Boga, stworzono w oparciu o istniejące już prawa. Za sprawą Deuteronomium pojęcie przymierza pomiędzy Jahwe a Izraelem zyskało centralną pozycję w myśli religijnej. Niewola babilońska, podobnie jak wcześniejsze wygnanie asyryjskie, pomogły umocnić w umysłowości żydowskiej przekonanie, że przymierze pozostawało uzależnione od spełnienia warunków i mogło być ewentualnie przez Boga rozwiązane poprzez nowe Objawienie ${ }^{19}$. Rolę pośrednika przymierza między Bogiem a Hebrajczykami przypisano Mojżeszowi, tradycyjnie kojarzonemu z cudownym wyprowadzeniem ludu z niewoli egipskiej. Wellhausen dostrzegał funkcjonujące w Biblii hebrajskiej dwie postaci Mojżesza - historyczną jako przywódcy oraz fikcyjną jako prawodawcy z Synaju, przedstawionego w najpóźniejszej, kapłańskiej redakcji $(\mathrm{P})^{20}$. Postać historyczną Mojżesza prezentuje tradycja jahwistyczna, w której został on opisany jako przywódca i sędzia, kierujący ucieczką Hebrajczyków

16 Ibidem, s. 417.

17 Ibidem, s. 418.

18 Ibidem.

19 Ibidem, s. 419.

20 Ibidem, s. 345-346; E.W. Nicholson, God and His People. Covenant and Theology in the Old Testament, Oxford 1986, s. 3-5. 
z Egiptu. Wcześniej był najprawdopodobniej przewodnikiem i doradcą, do którego zwracano się w trudnych chwilach po pouczenia i wskazówki ${ }^{21}$.

Analiza historii religii Izraelitów przywiodła Wellhausena do przekonania, że ich relacja $\mathrm{z}$ Bogiem ujęta $\mathrm{w}$ formę przymierza stworzona została przez profetyzm z VIII wieku p.n.e. Przed epoką profetyczną stosunki Jahwe z Izraelem miały charakter więzi naturalnej, podobnej do relacji łączącej ojca z dziećmi. Izraelici pojmowali Boga przede wszystkim jako opiekuna i obrońcę, który troszczy się o nich, zsyłając cenny deszcz i przynosząc zwycięstwo w wojnach. Opowieść o nadaniu prawa na Synaju w postaci aktu przymierza, stanowiąca ukoronowanie rozwijanej koncepcji przymierza, powstała w najpóźniejszej tradycji, po wygnaniu babilońskim, i miała na celu ukazanie całkowitej odmienności i transcendencji jedynego Boga oraz wyjątkowości Izraelitów wśród innych narodów. W ujęciu Wellhausena koncepcja przymierza miała więc wyłącznie teologiczny charakter.

\section{Przymierze jako instrument polityczny starożytnych Izraelitów}

Z teologicznym charakterem przymierza synajskiego w ujęciu Wellhausena kontrastowała teza Maxa Webera, który dowodził politycznej proweniencji i znaczenia tego pojęcia w swoim niedokończonym studium Das antike Judentum (1921). Jak stwierdził John Love, jest to prawdopodobnie najwybitniejsze dzieło Webera i najważniejsza część trzytomowego wydania Gesammelte Aufsätze zur Religionssoziologie22.

Analiza Webera rozpoczyna się od nakreślenia sytuacji geopolitycznej chłopsko-pasterskiej starożytnej Palestyny, pozostającej pod wpływem dwóch wielkich kultur: Egiptu i Mezopotamii. Według socjologa, początkowo Izrael funkcjonował politycznie jako plemienna konfederacja wojenna, zachowująca w miarę spójną jedność tylko w okresie wojen. Konfederacja ta, zdaniem Webera, nie posiadała żadnych trwałych instytucji przypominających instytucje polityczne, aparatu sądowego czy administracyjnego. Rolę czynnika jednoczącego plemiona pełniła wspólna wiara religijna, z naczelną ideą przymierza (hebr. berith). Ta ostatnia stanowiła w przekonaniu Webera wyraz racjonalizacji myślenia Izraelitów. Pierwotnie miała ona charakter utylitarny. Jako podstawa konfederacji plemion izraelskich przymierze ustanowione zostało nie z pobudek religijnych, lecz politycznych i służyło pierwotnie celom obronnym.

${ }^{21}$ J. Wellhausen, op. cit., s. 346.

22 J. Love, Max Weber's Ancient Judaism, [w:] The Cambridge Companion to Weber, S.P. Turner (red.), Cambridge 2000, s. 200. 
Zdaniem Webera, nie może dziwić fakt, że właśnie przymierze stało się podstawą izraelickiej konfederacji, od dawna bowiem wśród plemion zamieszkujących obszar dzisiejszej Palestyny służyło ono jako narzędzie regulowania relacji gospodarczych, przede wszystkim pomiędzy właścicielami ziemi a korzystającymi z niej pasterzami. Znaczenie przymierza wynikało więc z faktu, że pierwotny ustrój plemion izraelskich opierał się na, regulowanych umowami, związkach uzbrojonych patrycjuszy, posiadających ziemię, zorganizowanych w związki wojowniczych rodów, z posiadającymi status chronionych prawem metojków, określanych jako gerim (wędrowni pasterze, rzemieślnicy, kupcy). Strukturę społeczną i ekonomiczną wyznaczała cała sieć takich sojuszy ${ }^{23}$. Wyjątkowość berith polegała na niezmiernie szerokim zakresie jego stosowania, na traktowaniu go jako rzeczywistej podstawy najrozmaitszych związków, przede wszystkim na wyznaczaniu położenia prawnego wszystkich gerim $^{24}$.

Oparte na przymierzach relacje społeczno-polityczne poszczególnych plemion cechowały się jednak niestałością, z czym kontrastowała stabilność jednego znanego zakonu religijnego, czyli organizacji opartej na wspólnym kulcie. Takim związkiem kultowym byli Rekabici ${ }^{25}$. Ci pasterze i hodowcy bydła tworzyli stowarzyszenie oparte na fraternalizacji religijnej, czyli połączeniu rodów o różnym pochodzeniu etnicznym we wspólny związek kultowy. Rekabici uznali swój półkoczowniczy tryb życia i obyczaje za święte w przekonaniu, że jest to wypełnienie rozkazu płynącego z nieba, przekazanego im przez ich przodków ${ }^{26}$. Przykład Rekabitów unaocznił Hebrajczykom, że religia może być efektywnym instrumentem regulowania relacji ekonomicznych, a przede wszystkim politycznych, przydającym im stabilności. W przekonaniu Webera tego rodzaju okoliczności zadecydowały o przymierzu synajskim, będącym przymierzem militarnym, zawartym między plemionami w obliczu Jahwe i przymierzem z Jahwe jako związkowym bogiem wojny, pomocnikiem i sprzymierzeńcem. Przymierze to miało zatem polityczno-religijny charakter.

Pojęcie berith, umowy między Bogiem a jego ludem, do której obie strony przystępują dobrowolnie, było w przekonaniu Webera unikatowe w historii i miało wieloraki wpływ na rozwój religijno-społeczny. Historia Izraelitów interpretowana była w odniesieniu do tej wyjątkowej relacji łączącej ich z Bogiem. Jahwe wybrał ich jako swój lud i obiecał zniszczyć ich wrogów, Izraelici natomiast zobowiązali się przestrzegać jego przykazań, które w czasach konfederacji nie miały jeszcze charakteru etycznego, lecz społeczny, i oddawać mu

${ }^{23}$ M. Weber, Etyka gospodarcza religii światowych, t. 3: Starożytny judaizm, Kraków 2000, s. 83.

24 Ibidem, s. 78-79.

25 Ibidem, s. 83-85.

26 R. Bendix, Max Weber. Portret uczonego, Warszawa 1975, s. 194-195. 
cześć jako Bogu wojny. Do pierwotnej idei gniewnego Boga wojny z czasem dodane zostały cechy łagodzące jego wizerunek, takie jak sprawiedliwość i miłosierdzie. Koncepcja Boga jako partnera umowy stanowiła - zdaniem Webera - element racjonalny w religii Izraelitów, wyróżniający się na tle sąsiednich kultów bogów lokalnych i funkcjonalnych oraz kultów magicznych ${ }^{27}$.

Według Webera wojenna konfederacja Izraelitów, aż po czasy monarchii, nie posiadała trwałych instytucji politycznych w czasie pokoju. Czynnik integrujący stanowiła jedynie religia. W czasie wojny konfederacją rządziło zbrojne zgromadzenie Izraelitów (ēdâh), funkcjonujące jako ciało prawodawcze i sądownicze, przyjmujące przez aklamację wnioski przedłożone mu przez przywódców wojennych lub proroków. Powołując się na misję, zleconą im - jak wierzono - przez Jahwe, żądali uznania ich władzy poza granicami własnego plemienia. Władza centralna sprawowana była w czasie wojny przez charyzmatycznych bohaterów wojennych oraz w oparciu o autorytet sprawdzonych wyroczni i miejsc kultu związkowego Jahwe jako boga wojny (przede wszystkim Szilo). E Êâh wymierzał też sprawiedliwość przestępcom, którzy naruszyli prawo wojenne lub wystąpili przeciw obowiązującym rytualnym i społecznym przykazaniom Jahwe. Jak pokazuje drugie znaczenie èdâh - „zarządzenie”, mogło ono również wydawać ogólne rozporządzenia. Za wodza wojny związkowej uchodził sam Jahwe, z tego powodu prowadzona przez związek wojna uważana była za świętą ${ }^{28}$. Siłę zbrojną stanowiły w niej oddziały złożone z rolników i pasterzy, dowodzone przez, zajmujących się przepowiadaniem przyszłości i magią, proroków (nabi, l. mn. nebiim) oraz nazirejczyków (nasir - poświęcony, wybrany) - przywódców, jak wierzono, obdarzonych przez Jahwe charyzmą i mocą. Wrogami izraelskiej konfederacji wojennej byli przeważnie wojownicy na rydwanach - egipscy, kananejscy, filistyńscy. Zwycięstwo Izraelitom miał zapewniać Jahwe jako Bóg wojny, głównie poprzez wzbudzenie proroczej i bohaterskiej ekstazy. Zmieniło się to za czasów monarchii, zwłaszcza za panowania Salomona, posiadającego własną armię, którą stanowiły oddziały walczących na rydwanach wojowników i cudzoziemscy najemnicy. Nie było już wówczas miejsca - zauważa Weber - dla nebiim i nazirejczyków. Demilitaryzacja warstwy rolniczo-pasterskiej pociągnęła za sobą utratę ich znaczenia politycznego oraz zanik autorytetu nebiim i ich ekstazy. Prorocy ci stawali się stopniowo zawodowymi dworskimi ekstatykami, uprawiającymi proroctwa dla celów zarobkowych, bez związku z polityką związkową 29 .

27 J. Love, op. cit., s. 202-203.

28 M. Weber, op. cit., s. 92-93; R. Bendix, op. cit., s. 195-196.

29 M. Weber, op. cit., s. 102-103. 
Koncepcja przymierza z Jahwe jako Bogiem wojny oraz wizja całego Izraela jako konfederacji związanej przysięgą dochowania tego przymierza stanowiły starożytny kanon Izraelitów. W ujęciu Webera pierwotnym celem przymierza synajskiego był cel polityczny - wzmocnienie siły obronnej rozproszonych plemion izraelskich, zaś $\mathrm{w}$ ramach samych plemion przymierze to przydawało trwałości relacjom społeczno-ekonomicznym pomiędzy grupami społecznymi, przede wszystkim pomiędzy pasterzami drobnej trzody (kóz, owiec) a rolnikami posiadającymi ziemię lub wojskowym patrycjatem miejskim. Izrael rozwijał się i nabierał swego specyficznego charakteru jako związek kultowo-militarny, którego podstawę stanowili wolni pasterze i rolnicy, jednoczący się w czasie wojny przeciw wrogom.

$\mathrm{Z}$ weberowskim odczytaniem przymierza, w którym nacisk został położony na jego polityczną proweniencję i znaczenie, nie zgadzał się filozof religii Jullius Guttmann. Dowodził on tezy odwrotnej, mianowicie, że jedność religijna Izraelitów poprzedzała ich jedność polityczną. Zarzucał Weberowi niedostateczne zastosowanie metody verstehen oraz zbyt duże przywiązanie do czynników obiektywnych. Przypisując Izraelowi jako pierwotną jedność religijną, Guttmann wypominał Weberowi nadmierne upolitycznienie izraelskiej koncepcji Boga. Weber odrzucał takie quasi-teologiczne podejście na rzecz czystej naukowości, wychodząc z pozycji agnostycznej i antyteologicznej. Choć nie deprecjonował znaczenia doświadczenia religijnego, kładł dużo większy nacisk na pragmatyczne znaczenie, wywiedzionych z doświadczenia, charyzmatycznych jednostek idei religijnych w systemie społecznym. Mniej wagi przywiązywał do konstrukcji idei religijnej, więcej natomiast do czynników obiektywnych i do działania systemu jako całości. Socjologiczne zainteresowanie Webera, prowadzące do wyodrębnienia różnych grup o zróżnicowanym statusie, podawało w wątpliwość jedność Izraelitów, zakładało natomiast istnienie licznych konfliktów interesów. Udziałem Izraelitów, stanowiących amalgamat różnych grup, były te same konflikty, co u Kananejczyków. W analizie Webera nie ma większego znaczenia, czy właścicielami małych stad, gnębionymi przez miejski patrycjat, byli Kananejczycy czy Izraelici ${ }^{30}$. Weberowska koncepcja przymierza, jak już wspomniano, kontrastowała również z koncepcją Juliusa Wellhausena, dowodzącego ściśle teologicznego charakteru przymierza.

Co do początków Izraela Weber był zdania, że biblijnych patriarchów potraktować należy jako faktycznych przodków narodu izraelskiego. Przyznawał

30 A. Mittleman, Max Weber's Conception of Covenant in Ancient Judaism, with Reference to the Book of Judges, „Jewish Political Studies Review” 1994, no. 1-2, s. 21-23. 
autentyczność postaci Mojżesza ${ }^{31}$, który - jak sądził - najprawdopodobniej nie był Izraelitą, a wiarę w Jahwe przejął od swego teścia Jetro, uchodzącego za Madianitę. Religia Jahwe istniała przed jej recepcją przez Izraelitów, Bóg ten cieszył się zorganizowanym kultem wśród graniczących z Izraelem od południa Beduinów i plemion zamieszkujących oazy. Właściwym miejscem kultu była, zamieszkana przez Madianitów, oaza Kadesz na pustyni Synaj. Weber uważał, że mogły tam mieć miejsce wydarzenia, będące pierwowzorem opisanego w Biblii aktu zawarcia przymierza synajskiego. Mojżesz przejął religię od tutejszego kapłana Jetro ${ }^{32}$, a stało się to pod wpływem wydarzeń, opisanych w Biblii jako ucieczka z niewoli egipskiej. Grupa uciekinierów na czele z Mojżeszem swoje uwolnienie przypisywać zaczęła interwencji Boga Jahwe ${ }^{33}$. Zawarła z Nim przymierze, akceptując jego dotychczasowy kult, wyrażający się m.in. w zakazie przedstawień wizerunków, obrzezaniu, wyroczni losowej. Zasady te stanowiły rdzeń stowarzyszenia plemiennego. Weber przypuszczał, że podczas zgromadzeń przygotowujących kampanię wojenną ujawniali się nebiim, głoszący, że na czele wojsk kroczy Bóg wojny Jahwe, a plemiona uczestniczące w kampanii połączone są z nim przymierzem. Prowadziło to do wzmocnienia poczucia jedności i braterstwa, co nie pozostawało bez wpływu na militarną efektywność. Stąd pierwotne znaczenie słowa Izrael jako „ludzi Boga Wojny”34.

31 M. Weber, op. cit., s.123-124. Mojżesz był prorokiem, jednak innym w stosunku do ówczesnych proroków, przypominających czarowników, przepowiadających przyszłość na podstawie własnych snów. Jego wyjątkowość polegała na doświadczeniu epifanii, usłyszeniu głosu Boga. W tym upatrywano jego wyższości nad „śniącymi sny”, których wizje, zwłaszcza za czasów monarchii, zaczęto uważać za podejrzane i niepewne. O wyjątkowości Mojżesza, o jego wyższości profetycznej rozstrzygał osobisty kontakt z Jahwe, udział w „radzie” Boga. Prorocy okresu dwóch monarchii kontynuowali ten rodzaj proroctwa, ich wyrocznie oparte były na boskim nakazie czy natchnieniu, nie na snach i wizjach. Oparte na tych ostatnich proroctwa uznawano za nieklasyczne i zawodne, a samych wizjonerów za niewiarygodnych (ibidem, s. 107).

32 Ibidem, s. 120.

33 Zdaniem Webera, wydarzenia exodusu, pochłonięcie wojsk egipskich przez Morze Czerwone, jak i sam pobyt Izraelitów w niewoli egipskiej można podać w wątpliwość. Z drugiej jednak strony, w świetle źródeł egipskich, fakt, że stepowi hodowcy trzód w okresach zagrożenia szukali schronienia na pograniczu egipskim jako metojkowie nie był niczym nadzwyczajnym. Z dużym prawdopodobieństwem byli oni potem okazyjnie zmuszani przez królów egipskich do świadczeń feudalnych i, przy nadarzającej się okazji, próbowali się od tych ciężarów uwolnić. Chronologia imigracji i emigracji jest jednak niemożliwa do ustalenia. Weber zastrzegał też, że nie wszystkie plemiona Izraelitów przebywały w Egipcie i że napływały one falami na tereny zajordańskie z innych regionów, przystępując następnie do przymierza (ibidem, s. 122-123).

34 Jahwe nadawał się na boga wojny, pierwotnie był bowiem bogiem katastrof naturalnych, jego pojawianiu się towarzyszyły trzęsienia ziemi, wybuchy wulkanu, błyskawice. 
Jahwe - stwierdza Weber - był

i pozostał na zawsze bogiem zbawienia i obietnicy. Lecz najważniejsze było to, że zarówno zbawienie, jak i obietnice odnosiły się do aktualnych kwestii politycznych, a nie duchowych. Bóg przynosił zbawienie od niewoli egipskiej, a nie od przemijającego, bezsensownego świata, oraz obietnicę panowania nad Kanaanem, który Izrael pragnął podbić, i szczęśliwą tam egzystencję, a nie obietnice dóbr transcendentnych ${ }^{35}$.

Religia Izraelitów stanowiła odpowiedź na wyrażoną wolę Jahwe, a ponieważ jego pierwotnym celem było historyczne oswobodzenie Izraelitów i kierowanie nimi, judaistyczna koncepcja zbawienia nie miała charakteru bytowego, lecz polityczno-historyczny. W przekonaniu Webera $\mathrm{w}$ tym zawierał się zaczątek ascetyzmu wewnątrz świata, rozwijanego później przez kalwinizm $^{36}$.

Z politycznego punktu widzenia - dowodził Weber - Jahwe był od czasów Mojżesza Bogiem przymierza izraelskiej konfederacji i adekwatnie do celu tego stowarzyszenia - Bogiem prowadzonej przez nie wojny. Jak wspomniano, pierwotnie nie należał on do Izraelitów, ale był bogiem obcym i trzeba go było obrać. Obranie to nastąpiło za pomocą konceptu przymierza praktykowanego przez Hebrajczyków na polu społecznym i politycznym. Związek plemion przyjął Jahwe, podobnie jak później, również w oparciu o berith, związek ten ustanowił sobie króla. W rozumieniu Izraelitów również Jahwe, $w$ akcie suwerennej decyzji, wybrał sobie Izraelitów i złożył obietnice jak żadnym innym plemionom. Obok związkowej funkcji Boga wojny stawał się także partnerem umowy, ustanawiającej prawo związkowe, którym były początkowo przepisy prawa społecznego, przede wszystkim nakaz braterstwa oraz solidarności między Izraelem a Jahwe. Izraelita odmawiający pomocy związkowi plemiennemu,

Do katastrof zaliczano też plagi insektów, przede wszystkim szarańczy, przynoszonej przez południowo-wschodni wiatr. W przekonaniu Webera Jahwe postrzegany był właśnie przede wszystkim jako bóg zarazy. Na tę jego pierwotną funkcję wskazuje też wężowa laska kapłanów jahwistycznych w Jerozolimie. Obok budzącego trwogę wizerunku gniewnego boga, Jahwe w swej pierwotnej postaci postrzegany był zarazem jako bóg litościwy, a główny przejaw jego łaskawości stanowił życiodajny deszcz. Deszcz, od którego zależały interesy będących podstawą konfederacji rolników i pasterzy, stanowił główny czynnik ułatwiający przenikanie do obrazu Jahwe rysów dobrego boga natury i nieba. Ta sublimacja i racjonalizacja koncepcji boga w postać dobrego i mądrego zarządcy świata mogła dokonać się pod wpływem rozpowszechnionej wówczas na tym obszarze idei najwyższego boga niebiańskiego, za którego uznawany był El. Niemniej jednak, aż do powrotu z wygnania babilońskiego przeważał wizerunek Jahwe jako przerażającego boga katastrof, a nie boga wiecznego porządku (ibidem, s. 125-127).

35 Ibidem, s. 124.

36 A. Mittleman, op. cit., s. 16-17. 
niestawiający się na wezwanie do wojny, gardził jednością z samym Jahwe ${ }^{37}$. Wśród skonfederowanych istniały różnice majątkowe i sprzeczności interesów, przekładające się na konflikty wewnętrzne. Zdaniem Webera, celem ustanowionego przez Mojżesza prawa społecznego mogło być łagodzenie tych konfliktów. Mojżesz był więc ajsymnetą, kimś pomiędzy prorokiem a prawodawcą, którego rola polegała na nadaniu prawa i uwierzytelnieniu go przez Boga, by tym sposobem doprowadzić do złagodzenia konfliktów społecznych i wypracowania stanowego kompromisu ${ }^{38}$. Przykładem takiego działania było ustanowione przez Solona prawo „strząśnięcia ciężarów” (gr. seisachtheia) ${ }^{39}$, mające swój biblijny odpowiednik w roku darowania długów i przywracania wolności niewolnikom (Wj 21:2-6; Kpł 25:1-7; Pwt 15:1-18). Jahwe przyjmował tym samym również rolę Boga społecznego, jego więź z Izraelitami oparta na berith zakładała priorytet przykazań społecznych, ofiara natomiast schodziła na plan dalszy. Wierzono, że była ona miła Jahwe, ale nie niezbędna. Jak podkreślał Weber, w epoce przedmonarchicznej nie istniała żadna instancja polityczna czy hierokratyczna zajmująca się składaniem ofiar w imieniu konfederacji, nie było też, akceptowanej przez związek, warstwy kapłańskiej ${ }^{40}$. Do czasów, kiedy przykazania wynikające $\mathrm{z}$ berith miały pierwszeństwo przed ofiarą, $\mathrm{w}$ epoce monarchicznej nawiązywali prorocy, popierani przez grupy społeczne żyjące w największym oddaleniu od miejsc kultowych, czyli rolników i hodowców drobnej trzody ${ }^{41}$.

37 M. Weber, op. cit., s. 127-128. W Deuteronomium, nowej redakcji Księgi Wyjścia, nakaz braterskiej solidarności rozwinięty został w zaawansowane przepisy społeczne, służące ochronie wdów sierot, parobków, robotników, chorych (ibidem, s. 70-77). Deuteronomium zrywało z segregacją osiadłych cudzoziemców i przyjęło zasadę jednego prawa dla wszystkich, zarówno Izraelitów, jak i nie-Izraelitów. Jako dzieło kapłanów jerozolimskich, stanowiło uwieńczenie postępującego procesu teologizacji prawa i izraelskiego porządku społecznego, z drugiej strony zapoczątkowało proces racjonalizacji etyki religijnej, który swoje apogeum osiągnął w ramach ruchu profetycznego.

38 M. Weber, Gospodarka i społeczeństwo. Zarys socjologii rozumiejacej, Warszawa 2002, s. $347-348$.

39 Umorzenie długów chłopów attyckich, zaciągniętych u możnych pod zastaw swych gruntów. Nie mogąc ich spłacić, chłopi ci tracili ziemię, która przechodziła na własność wierzycieli, a sami stawali się niewolnikami za długi.

${ }^{40}$ M. Weber, Etyka gospodarcza..., s. 132, 155.

${ }^{41}$ Ibidem, s. 132-133. 


\section{Racjonalizacja i etyzacja religii następstwem profetycznej interpretacji przymierza}

Według Webera, przymierze było kluczowym elementem, umożliwiającym stopniową ewolucję w kierunku racjonalizacji etyki w ramach ruchu profetycznego. Początkowo usankcjonowane religijnie przykazania społeczne miały bardziej charakter prawny niż etyczny. W procesie transformacji ku etapowi, określanemu przez Webera jako etyczna racjonalizacja, priorytetowe znaczenie miała religijność, odmienna od dotychczasowej, zainspirowana przez proroków, którzy pojawili się w okresie późnej konfederacji i zyskali na znaczeniu za czasów monarchii, zwłaszcza w okresach zagrożenia zewnętrznego. Kryzysy polityczne i społeczne tłumaczyli nieprzestrzeganiem przez Izraelitów przykazań Jahwe, zawartych w przymierzu z czasów konfederacji. Tym samym wskazywali, że źródło niepowodzeń i konfliktów tkwiło w samych Izraelitach, którzy swym bałwochwalstwem i niesprawiedliwością wzbudzali gniew Jahwe. Profetyzm prowadził tym samym do rozwoju sfery indywidualnego sumienia, konfrontującego się z konkretnymi, zrozumiałymi dla wszystkich, przykazaniami Jahwe. Można było dać odpowiedź na pytanie, jakich przykazań Izraelici nie przestrzegali i wytłumaczyć w ten sposób ich niepowodzenia polityczne. Fakt, że konfederacja i jej religijność opierały się na warstwach chłopskich i pasterskich oraz na wojowniczych rodach, nie sprzyjał, zdaniem Webera, rozwojowi etycznej racjonalizacji. Jak dowodził, im bardziej dany rozwój kulturowy miał chłopski charakter, tym bardziej przeważał tradycjonalizm i w tym mniejszej mierze religijność ludową cechowała etyczna racjonalizacja ${ }^{42}$. Również szlachta wojowników nie była nośnikiem racjonalnej etyki religijnej, sposób życia wojownika nie wiązał się bowiem z ideą dobrej opatrzności czy systematycznych etycznych wymagań Boga. Pojęcia takie jak grzech, zbawienie, religijna pokora obce były poczuciu godności wszystkich politycznie panujących, przede wszystkim szlachcie wojowników. Stawianie czoła śmierci i irracjonalizmowi ludzkiego losu było dla nich codziennością. Od religii oczekiwali głównie ochrony przed złymi czarami i ceremonii rytualnych, licujących z ich stanowym poczuciem godności, ewentualnie - kapłańskich modlitw o zwycięstwo, czy też o prowadzącą do nieba, bohaterską śmierćt3.

Już w schyłkowym okresie konfederacji następowały istotne zmiany w strukturze społecznej Izraelitów, zaostrzały się dysproporcje pomiędzy żyjącymi poza miastami rolnikami i pasterzami a miejskimi patrycjuszami wojskowymi. Zmiany te uległy pogłębieniu wraz z powstaniem monarchii, z którym wiązał

42 M. Weber, Gospodarka i społeczeństwo..., s. 367.

43 Ibidem, s. 370. 
się proces urbanizacji i towarzyszące mu nasilanie się antagonizmów pomiędzy biednymi a bogatymi. Tylko miejskich patrycjuszy, posiadających ziemię i czerpiących z niej dochody, stać było na uzbrojenie i zaopatrzenie oddziałów wojskowych. Stąd brało się ich znaczenie polityczne, opierające się wówczas na pozycji militarnej. Monarchia ewoluowała w kierunku wzorców sąsiednich despocji. Pozostawało to w związku ze wspomnianym wzrostem znaczenia miast i patrycjatu miejskiego, kosztem gerim i drobnych rolników, których udziałem stała się demilitaryzacja i pauperyzacja. Według Webera, powodem przejmowania przez miejskich patrycjuszy bogów kananejskich, zwłaszcza Baala ${ }^{44}$, było to, że idealnie komponowali się oni z ich wyniosłym usposobieniem. Religijne i społeczne aspiracje zbrojnych patrycjuszy rodziły wrogość proroków, domagających się przywrócenia dawnych nomadzkich ideałów z czasów konfederacji, poprzez ożywienie dawnego kultu Jahwe jako Boga przymierza,

${ }^{44}$ Hebr. Báál, 1. mn. Be’alìm - słowo należące do najstarszej warstwy języka semickiego, oznaczające „pana”, „właściciela”. Pośród ludów semickich (kananejskich) słowo w różnej swej formie (Báál na zachodzie i południu; Bel w Asyrii; Bal, Bol czy Bel w Palmyrze) oznaczało bóstwo władające światem lub jego częścią. Jednak Baale różnych plemion, miejsc czy sanktuariów nie były identyczne, każde bóstwo miało swoją naturę i swoje imię. W sztuce wyobrażano sobie Baala jako wojownika w szpiczastym hełmie ozdobionym rogami. W jednej ręce dzierżył maczugę, w drugiej błyskawicę - jego boski atrybut. Religia boga Baala była dość powszechnie akceptowana wśród starożytnych Izraelitów i chociaż walczono z tym kultem, to jednak nigdy nie został on na stałe stłumiony. Królowie i elity, zwłaszcza w państwie północnym, czcili Baala, podobnie jak zwykli ludzie, którzy uważali, że ich powodzenie, wydajność upraw i dobrostan zwierząt gospodarskich, uzależnione są od tego boga deszczu i słońca. Jego wizerunki widniały na wielu budynkach. Pojawiali się kapłani i różne klasy wielbicieli. Uroczystości składały się z kadzenia i całopalenia ofiar, czasami składano ofiary z ludzi. Kapłani tańczyli wokół ołtarzy, wznosili gorączkowe śpiewy i cięli się nożami, by wzbudzić zainteresowanie i współczucie bóstwa (A.G. Hefner, Baal, Encyclopedia Mythica from Encyclopedia Mythica Online, http://www.pantheon.org/articles/b/baal.html [dostęp: 9.08.2013]). Baal nie był jednak najwyższym bogiem Kanaanu. Szczyt tamtejszego panteonu należał do Ela, stwórcy wszelkich stworzeń, dostojnego ojca i króla bogów i ludzi. El uważany był za boga wszechmocnego, mądrego, dobrotliwego, łaskawego i miłosiernego, za najwyższego sędziego, orędownika sprawiedliwości, miłosierdzia, gościnności i obyczajności, przymiotów, które istoty ludzkie powinny starać się posiąść. Z tego powodu królowie kananejscy, kierujący obrzędami religijnymi w swych miastach-państwach, mieli obowiązek, jako przedstawiciele woli boskiej na ziemi, okazywać sprawiedliwość i miłosierdzie ludziom upośledzonym i bezbronnym. Najbardziej znanym bóstwem żeńskim była Aszera, występująca w niektórych regionach Kanaanu jako żona Ela, w innych zaś jako żona Baala. Były okresy, że także niektórzy Izraelici traktowali Aszerę jako żonę Jahwe. M. Grant, Dzieje dawnego Izraela, Warszawa 1991, s. 35-40, http://www.opracowanie. eu/grant.htm [dostęp: 9.08.2013]. 
dla którego nakazy wynikające $\mathrm{z}$ berith miały pierwszeństwo przed ofiarą ${ }^{45}$. Jak pisze Weber, nawet jeśli nałożone pierwotnie przez Jahwe na konfederację wojenną przykazania były prymitywne, czego nie sposób z całą pewnością stwierdzić, to jednak widoczne było w nich przykładanie o wiele większej wagi, niż w przypadku innych ówczesnych bogów, do wypełniania określonych rytualnych i społeczno-etycznych norm. Jahwe nie był wówczas jeszcze traktowany jako Bóg ceniący sobie wiecznie obowiązującą moralność, taki wizerunek był "produktem” późniejszego racjonalizmu intelektualistów. W rozumieniu Izraelitów Bóg konfederacji zachowywał się jak król, stawał się gniewny i zapalczywy, kiedy nie wychodzono naprzeciw pozytywnie sformułowanym nakazom, gwarantowanym mu przez berith, czego on, władca, oczekiwał od swoich poddanych ${ }^{46}$. Wprawdzie był Bogiem na wysokościach, jednak jego ziemskie zakorzenienie trudno było zignorować. Miał cechy człowieka, któremu nic co ludzkie nie było obce, łącznie z chimerycznością i wybuchowością.

Jak wiadomo, wraz z rozwojem Izraela rysowały się coraz wyraźniej konflikty pomiędzy różnymi grupami społecznymi, zwłaszcza pomiędzy miejską arystokracją wojenną, posiadającą ziemię (gibbor - wojownik, 1. mn. gibborim), a rolnikami i pasterzami, którym dawała się we znaki pańszczyzna i niewolnictwo za długi ${ }^{47}$. Tradycja biblijna grupie miejskich bogaczy przeciwstawiała północnoizraelskich rolników i pasterzy judzkich. To rolnik Saul i pasterz Dawid jako przedstawiciele dwóch typowych kategorii Izraelitów stawili czoła filistyńskim ciężkozbrojnym ${ }^{48}$. Ta gloryfikacja chłopskiej religijności, jaką w dużej mierze była pierwotna religijność izraelickiego związku wojennego, stanowiła późniejszy produkt literackiej działalności intelektualistów, opozycyjnych wobec mieszczańskiego sposobu życia okresu monarchii. Chłopi bowiem, jak przekonywał Weber, tworzyli warstwę, będącą nośnikiem niemagicznej, racjonalnej religijności, jedynie w wyjątkowych przypadkach. Źródła religijnego racjonalizmu tkwiły w pobożności miejskiej ${ }^{49}$.

45 J. Love, op. cit., s. 203; M. Weber, Starożytny judaizm..., s. 132-133.

${ }_{46}$ M. Weber, Etyka gospodarcza..., s. 133.

47 Ibidem, s. 63.

48 Ibidem, s. 53, 63.

49 Religijność późniejsza, zwłaszcza w okresie faryzejskim, wyglądała zupełnie inaczej. W pobożności gminy prawowiernych Żydów (chaberim) okresu późnego judaizmu wieśniak uważany był za bezbożnika, a człowiek niemieszkający w mieście, zarówno religijnie, jak i politycznie - za Żyda drugiej kategorii. Ta pogarda wobec chłopa wiązała się z faktem, że praktycznie nie mógł on żyć w zgodzie z przykazaniami żydowskiego prawa rytualnego. Teologia probabilońska, a jeszcze bardziej talmudyczna teologia rabiniczna, w swych praktycznych konsekwencjach utrudniały zajmowanie się pracą rolniczą (M. Weber, Gospodarka i społeczeństwo..., s. 368-369). 
Monarchia izraelska osiągnęła swoje apogeum za rządów Salomona, który stworzył bogaty i potężny rząd centralny, jakiego Izraelici nigdy nie znali oraz zbudował świątynię w Jerozolimie ${ }^{50}$. Jednak koszt funkcjonowania monarchii w takim kształcie był niewiarygodnie duży. Za wystawny i ekstrawagancki sposób bycia swego dworu Salomon płacił rozdawnictwem ziemi i wysyłaniem Izraelitów do pracy przymusowej. Kiedy umarł (pod koniec X wieku p.n.e.), plemiona północy odmówiły podporządkowania się władzy jego syna Roboama, ustanawiającego kulty pogańskie. Zapoczątkowany został podział kraju na dwa królestwa: Izraela ze stolicą w Sychem (później Samaria) i Judy, ze stolicą $\mathrm{w}$ Jerozolimie, które $\mathrm{w}$ ówczesnych warunkach geopolitycznych nie miały szans na dłuższe trwanie. W 701 roku p.n.e. Izrael podbili Asyryjczycy. Izraelskie znaczące rody zmuszone zostały nie tylko do przemieszczenia się w inne części imperium asyryjskiego, ale także do rozproszenia. $Z$ powodu tego ostatniego ta protodiaspora zatraciła $\mathrm{z}$ czasem wiarę $\mathrm{w}$ Jahwe i swą tożsamość. Tradycja określa ją jako dziesięć zaginionych plemion Izraela. Późniejszy podbój królestwa Judy przez Babilończyków (597-586 rok p.n.e.) wyglądał inaczej. Podczas ekspedycji karnej do Judei (597 rok p.n.e.), w wyniku której Nabuchodonozor II uprowadził około 10 tysięcy ludzi, jak i po ostatecznym podboju w 586 roku p.n.e., kiedy uprowadzonych było dużo mniej, pomiędzy 800 a 1600 osób, pozwolono Izraelitom, by w Babilonie osiedlili się jako zwarta społeczność, dzięki czemu mogli kontynuować swoją wiarę w Jahwe i oprzeć się wpływom obcego otoczenia.

Ruch profetyczny zapoczątkowany został już w czasach Samuela w XI wieku p.n.e., a rozwinął się za czasów dwóch królestw. W okresie monarchicznym zmniejszenie zagrożenia zewnętrznego było zazwyczaj pozytywnie skorelowane z nasilaniem się kultów obcych bogów, co dawało powód do aktywności proroków, ganiących pogańskie obrządki, zwłaszcza kult kananejskiego boga Baala/Baalów w Królestwie Północnym. Stałym motywem prorockiej retoryki było nawoływanie do wierności w przymierzu z Jahwe z czasów konfederacji. To stare przymierze oraz związane z nim braterstwo i prostota obyczajów stało się głównym tematem prorockich pieśni. Obok aspektu religijnego działalność proroków miała również aspekt społeczny, ich sprzeciw budził despotyczny charakter władzy królów izraelskich i judzkich oraz ich niesprawiedliwość względem ludu.

Profetyzm okresu monarchicznego - zauważał Weber - nie był profetyzmem dawnych nabiim, mającym bardziej wojowniczy charakter. Nowy typ proroka,

50 Jak w przypadku wszystkich wydarzeń opisanych przez Biblię, także istnienie słynnej świątyni Salomona budzi spory wśród badaczy. Według niektórych archeologów świątynia ta powstała dopiero 200 lat po śmierci Salomona, tj. w połowie VIII wieku p.n.e. 
zapoczątkowany przez Eliasza w IX wieku p.n.e., różnił się od dawnego męża bożego tym, że jego działalność cechowała się pacyfizmem, a proroctwo skierowane było nie tylko do króla czy starszyzny, ale również do ludu, a przynajmniej do tej jego części, która wyrażała zainteresowanie sprawami publicznymi. Prorok obdarzony był czysto osobistą charyzmą i głosił religijną naukę lub boski nakaz, nie posługując się przy tym środkami magicznymi czy ekstatycznymi, lecz wezwaniem Boga w modlitwie. Odróżniał się od dawnych nabiim również pod względem ekonomicznym: za swe prorokowanie nie pobierał pieniędzy, propagował idee religijne dla nich samych ${ }^{51}$. Eliasz zapoczątkował działalność profetyczną, kontynuowaną przez szereg wybitnych postaci, takich jak: Amos, Ozeasz, Izajasz, Jeremiasz, czy Ezechiel. Prorocy ci uosabiali duchową, bezinteresowną opozycję przeciw sprawowanym na dworze kultom bogów kananejskich i królewskiemu uciskowi, jakiego doświadczali rolnicy i pasterze, niegdysiejsi przedstawiciele wojsk związkowych. Prorocy okresu królewskiego - pisze Weber - byli przywódcami religijnymi, niezależnymi od istniejącej władzy politycznej, a często otwarcie wobec niej opozycyjnymi. W okresach narastania zagrożenia zewnętrznego działali publicznie, przemawiając do ludu na ulicach lub zwracając się do niego w listach otwartych, powodowani zawsze osobistą, spontaniczną inspiracją. Ich główną troską był los państwa i ludu. Elementy proroctw stanowiły przekleństwa, groźby, inwektywy kierowane pod adresem władców, wyrazy rozpaczy i gniewu. Nieskrępowani ani obyczajami, ani samokontrolą prorocy kierowali się jedynie pragnieniem przywrócenia chwały jedynemu Bogu. Względy osobiste czy polityczne nie miały znaczenia. Uważali, że stosunki polityczne na ziemi są dziełem Jahwe i tylko on może je zmienić. W związku z tym, niechętnie odnosili się do sojuszy politycznych, bowiem implikowały one wiarę w skuteczność ludzkiego działania i niewiarę w potęgę Jahwe oraz jego specjalne przymierze z Izraelem. Religijne podejście do wydarzeń politycznych sprawiało często, że prorocy nie liczyli się z realiami. Ich znaczenie opierało się na przepowiedniach klęsk politycznych w czasach względnego dobrobytu i stabilizacji lub powodzeń i sukcesów politycznych w czasach klęsk i nieszczęśśc ${ }^{52}$. Prorocy byli zwykle samotnikami przedstawiającymi swe apokaliptyczne wizje przyziemnym zainteresowaniom ludzi swoich czasów, ich natchnienie poprzedzały różne patologiczne stany psychiczne. Nie dążyli jednak do uprawomocnienia swej działalności za pomocą cudów czy ekstazy, co miało ich odróżniać od "fałszywych proroków”, którzy zamiast słów Jahwe opowiadali sny. Swoją misję oddzielali od osobistego zachowania. Niewiele mieli wspólnego z ekstatykami z okresu konfederacji, chociaż stany

51 M. Weber, Etyka gospodarcza..., s. 108; idem, Gospodarka i społeczeństwo..., s. 346-347.

52 R. Bendix, op. cit., s. 216-218. 
psychopatyczne stanowiły atrybut wszystkich rodzajów profetyzmu ${ }^{53}$. Działalność proroków nie była możliwa w okresach względnej stabilizacji, zabraniała jej wówczas władza królewska, uważając wygłaszanie proroctw za wewnętrzną sprawę dworu i tamtejszych dworskich proroków.

Prorocy pojawili się w okresie przemian struktury politycznej, a przez to i społecznej, Izraela, wywołanych powstaniem monarchii, niestabilnością wewnętrzną i narastającym zagrożeniem zewnętrznym. Prywatne grzechy królów i ich społeczna niesprawiedliwość stanowiły główny przedmiot prorockich lamentacji. Przekształcenie się Izraela w państwo liturgiczne na wzór Egiptu, wobec którego Izraelici zawsze akcentowali swoją niechęć, oraz wprowadzenie do armii rydwanów stanowiły dla proroków źródło największego zła. Aparat biurokratyczny i przymus świadczeń na rzecz państwa uznawali za egipską obrzydliwość, za które należy się kara boża w postaci plag. Odpowiadało to wyobrażeniom ludu, izraelscy rolnicy i pasterze mieli świadomość, że kiedyś ich przodkowie walczyli przeciw miejskim wojskom obcych wrogów. Teraz we własnym państwie odczuwali polityczną i ekonomiczną przewagę króla i miejskiego patrycjatu, jako dzierżawcy popadali w coraz większe, prowadzące do niewoli zadłużenie. Broniący ich prorocy opiewali czasy, kiedy sam Jahwe przewodził armii rolników, domagali się, by królowie podobni byli do dawnych, jadących na ośle przywódców izraelickich, by porzucili charakterystyczny dla Salomona despotyzm, pozbyli się rydwanów, haremu, nie stosowali przymusowych robót i przestrzegali praw Mojżeszowych oraz nie zdawali się na cudzoziemskie sojusze, lecz tylko na przymierze $z$ Jahwe ${ }^{54}$. Krytycyzm ten - podkreślał Weber - ugruntował znaczenie Prawa. Prorocy, wskazując odstępstwa od przykazań przymierza z Jahwe jako źródło niepowodzeń, stymulowali rozwój świadomości prawnej, torując tym samym drogę racjonalnej etycznej religijności.

Idealizacja dawnych ludowych książąt prowadziła do rewizji starej tradycji biblijnej, według której Saula pomazał prorok Samuel, Dawid był pasterzem, a każdego króla oceniano według kryterium religijnego: czy był pobożnym jahwistą, czy też bałwochwalcą. Idee te sformułowano pod rządami Jozjasza (639-609), na które przypadła działalność proroka Jeremiasza (zm. po 585 roku), jak i odkrycie Deuteronomium pod koniec VII wieku przed Chrystusem i tzw. reforma deuteronomiczna, zrywająca z systemem zdecentralizowanych praktyk religijnych i ustanawiająca świątynię jerozolimską jedynym właściwym miejscem kultu.

Tradycja deuteronomiczna włożyła w usta Samuela, opiewanego jako proroka i przedstawiciela starego prawa, opis znienawidzonego prawa królewskiego. Opowieść o pokonaniu Goliata przez Dawida procą z kamieniem, bronią typowo rolniczą - zdaniem Webera - również wpisywała się w nurt tradycji wrogiej

${ }^{53}$ Ibidem, s. 220-221.

54 M. Weber, Etyka gospodarcza..., s. 110-111. 
monarchicznym porządkom, gloryfikującej czasy konfederacji, chłopskiej armii, braterskiej równości i prostoty, czyli czegoś w rodzaju „koczowniczego ideału" ${ }^{5}$. Pozostając pod wrażeniem upadku pozycji politycznej wiejskich prowincji, nurt deuteronomiczny akcentował fakt, że zanim Izrael został monarchią, bezpośrednią i niepodzielną władzę nad nim sprawował sam Jahwe, który nie potrzebował, tak jak współcześni królowie, całego aparatu urzędów, podatków i danin. Jahwe objawiał swoją wolę ludowi za pomocą dawnych proroków i wizjonerów i, jeśli lud okazywał posłuszeństwo przykazaniom, nie pozostawał bez boskiej pomocy. W ramach reformy deuteronomicznej oczekiwano od królów usunięcia typowo monarchicznych innowacji: likwidacji organizacji militarnej opartej na jeździe i rydwanach, skarbu koronnego, haremu cudzoziemskich księżniczek i uprawianego przez nie kultu obcych bogów, urzędników jako królewskich beneficjentów, pańszczyzny poddanych na budowach i polach królewskich. Monarcha miał porzucić władcze maniery i zachowywać się jak charyzmatyczny primus inter pares, jak jeżdżący na ośle mądry sędzia i obrońca prostego ludu. Wówczas Bóg przymierza Jahwe miał stanąć u jego boku, tak jak kiedyś stał na czele chłopsko-pasterskiej armii ${ }^{56}$.

Za czasów świetności władzy królewskiej pamięć o Mojżeszu i przymierzu zaniknęła, jednak w okresie dwóch królestw i na wygnaniu zaczęła zyskiwać na znaczeniu. Stanowiło to naturalną konsekwencję upadku politycznego Izraelitów oraz pytania o przyczyny tego stanu rzeczy. Stare prawo związkowe i znaczenie przestrzegania przykazań jako warunku łaski Jahwe zaczęly odgrywać dominującą rolę i odcisnęły wyraźne piętno na nadziejach na przyszłość, a idea przymierza nadała specyficzną dynamikę koncepcjom etycznym nauk kapłańskich i profetycznych ${ }^{57}$.

Idealizując federacyjną przeszłość, prorocy przestrzegali przed zniewoleniem, jakie niosła ze sobą monarchia despotyczna i nadużyciami ze strony monarchów oraz ich patrycjuszowskich popleczników, wskazując zarazem powrót do przestrzegania przykazań zawartych w przymierzu jako jedyny sposób uniknięcia tej patologii. Do kluczowych pojęć epoki profetycznej należały mishpat (sprawiedliwość) i sdaqa (prawość) ${ }^{58}$. Prorocy, tacy jak Eliasz ${ }^{59}$, Amos $^{60}$,

55 Ibidem, s. 113.

56 Ibidem, s. 115.

57 Ibidem, s. 118.

58 J. Love, op. cit., s. 207.

59 Eliasz (z hebr. 'Jahwe jest Bogiem'), żył w pierwszej połowie IX wieku p.n.e. Występował przeciwko królowi Achabowi (IX wiek p.n.e.) i jego żonie Jezabel, szerzących w Izraelu kult Baala i Aszery. Eliasz (jego historię opowiadają Księgi Królewskie) bronił wiary w Jahwe, wypominał królowi zdradę przymierza, ubolewał nad utratą tożsamości swego narodu, odmawiającego wierności jedynemu i prawdziwemu Bogu.

${ }^{60}$ Jako prorok pojawił się prawdopodobnie w roku 750 p.n.e. Nazywany prorokiem sprawiedliwości społecznej, pochodził z Judei, z miasteczka Tekoa, działał jednak w Izraelu. 
Ozeasz $^{61}$, Izajasz ${ }^{62}$, czy Jeremiasz, nie cieszyli się poważaniem wśród Izraelitów, nawet wśród najniższych warstw, w których interesie występowali. Ganili oni bowiem politeizm Izraelitów, powszechny również wśród plebejuszy, stawiając $\mathrm{w}$ ich miejsce wymagania moralne na czele $\mathrm{z}$ wiarą $\mathrm{w}$ jedynego Boga Jahwe. Pozostawali też w konflikcie z kapłanami, zwłaszcza jerozolimskimi, mającymi od czasu reformy deuteronomicznej monopol kultowy, których ganili za zbytnie przywiązanie do zewnętrznych form rytualnych. Prorocy ci opierali się na inspiracji charyzmatycznej, powoływali się na słyszane słowo Boga (dawar), którego, jak twierdzili, byli przekazicielami. Nie uważali się natomiast za naczynia Boga, co było typowe dla wirtuozów religii wschodnich. Uwaga proroków - podkreślał Weber - nie koncentrowała się na kwestiach mistycznych ani na metafizycznych spekulacjach dotyczących świata, nie poszukiwali oni doskonałości duszy w opozycji do niedoskonałego świata, nie czuli się zjednoczeni z boskością i uwolnieni od doświadczeń życia. Zadaniem, które sobie stawiali, było zrozumienie bożych sądów i ich implementacja w ówczesnej rzeczywistości. Natura Boga nie zawierała bowiem niczego, czego nie obejmowałoby ludzkie zrozumienie. Najważniejszym żądaniem stawianym przez proroków nie była miłość, lecz wiara, co wiązało się z nauką posłuszeństwa i pokory jako głównych cnót i bezgranicznym zaufaniem Jahwe jako wszechmocnemu

Był pasterzem owiec i wołów, miał również sad z drzewami sykomorów. Nie należał zatem do ludzi biednych, jednak to w ich imieniu występował. Uwrażliwiony na nędzę i niesprawiedliwość, jakiej doświadczali drobni rolnicy i pasterze, nawoływał dwór i związane z nim środowiska kapłanów i bogaczy, by zmienili swoje postępowanie. Prorokował podbój Izraela przez Asyryjczyków.

${ }^{61}$ Ozeasz (750-725 p.n.e.) działał w tym samym czasie co Amos, również w Królestwie Północnym. Ten północnoizraelski rolnik głównym przedmiotem swej działalności uczynił kult Baala jako największego konkurenta Jahwe. W jego proroctwie Jahwe jest przedstawiany jako odtrącony i znieważony małżonek Izraelitów. Izraelici to, według Ozeasza, niewierna oblubienica, uprawiająca nierząd z kochankami - Baalami, przekonana, że to oni dają jej „chleb i wodę, wełnę, len i napoje”. Ozeasz jako pierwszy widział w przymierzu Boga z Izraelem przede wszystkim związek miłości, podobny do jego własnego małżeństwa z prostytutką Gomer.

${ }^{62}$ Izajasz (765-701 p.n.e.) piętnował wady widoczne w różnych sferach społeczeństwa judzkiego, zwłaszcza pychę i zbytek, zepsucie moralne, wyzysk i ucisk klas niższych, niesprawiedliwość w wyrokach sądowych i w nakładaniu świadczeń publicznych, praktyki wróżbiarskie i formalizm w zewnętrznym kulcie Jahwe. Przepowiadał klęskę narodu i zarazem obiecywał ocalenie niezepsutej cząstki Izraela, z której miał się odrodzić nowy, święty naród. Izajasz był największym prorokiem mesjańskim. Wiele z prawd nauki objawionej w Nowym Testamencie ma swój początek już w Izajaszu, np. nauka o odkupieniu ludzkości przez śmierć Mesjasza, nauka o konieczności łaski bożej do dobrego i o usprawiedliwieniu z wiary przez łaskę, nauka o przymiotach Boga, zwłaszcza o jego sprawiedliwości. 
sprawcy wszystkiego ${ }^{63}$. Naturalnie, istotne znaczenie miało przestrzeganie powszechnie znanych przykazań. Prorocy nie tworzyli nowej koncepcji Boga ani nowych zasad, warunkiem wstępnym całego profetyzmu było istniejące prawo. Nauczanie proroków koncentrowało się na etycznie poprawnym zachowaniu w sytuacji tu i teraz, w rzeczywistości dnia codziennego. Głoszone nieszczęście traktowali jako konsekwencję braku szacunku dla ogólnie obowiązujących nakazów Jahwe. Respektowanie nakazów etyki codziennej uchodziło za obowiązek Izraelity, wynikający z zobowiązania przodków wyrażonego w berith. Patos eschatologicznych gróźb i obietnic był dodatkowym elementem wpływającym na zachowanie tych prostych przykazań, których każdy był w stanie przestrzegać. Specyficzne, obiecane Izraelowi zbawienie zależało w zupełności od etycznie poprawnego działania w świecie, działania zgodnego z zasadami moralności powszechnej. Działalność proroków nie dotyczyła kultu, jej przedmiotem była wyłącznie etyka ${ }^{64}$. Prorocy nią się tylko interesowali i stawiali ją w centrum politycznej wspólnoty narodowej. Zagrożenie zewnętrzne prowokowało zadawane przez nich pytania, jakich wykroczeń przeciw berith dopuścili się Izraelici czy ich przodkowie. Przepowiadane przez nich nieszczęścia stanowiły produkt głębokiej odrazy wobec odstępstwa od berith oraz lęku przed następstwami tego stanu rzeczy, ale też wytwór niewzruszonej wiary w obietnice Jahwe i rozpaczliwej pewności, że lud roztrwonił szanse na ich spełnienie lub że był tego bliski ${ }^{65}$. Ze względu na charakter ich proroctw udziałem profetów nieszczęścia była samotność; nikt nie chciał słuchać wieszczenia nieszczęść. Ekscentryczność i bezkompromisowość uczyniła z nich jednak ideologów jahwizmu i działaczy politycznych ${ }^{66}$. Przy nacisku położonym na, stanowiący nowość, etyczny wymiar wiary prorocy powracali do wizerunku Jahwe jako Boga organizacji politycznej (dawnej konfederacji, jak twierdził Weber), co oznaczało, że traktowali go nie jako Boga wiecznego ładu, lecz jako funkcjonującego w świecie Boga działania ${ }^{67}$. Zorientowanie profetyzmu na politykę wyrażało się w jego nieustannym zainteresowaniu losem narodu w wymiarze doczesnym. W stosunku do jednostki profetyzm uznawał prawomocność zasady Jahwe, wyrażającej się w krwawej zemście i wojnie, to znaczy potwierdzał odpowiedzialność jednostki za czyny swoich współplemieńców oraz za złe, nieodpokutowane uczynki swoich przodków. Wykroczenia przeciwko obowiązkom przymierza zdarzały się w przeszłości i w każdej chwili można było je łatwo wskazać. W związku z tym profetyzm zakładał istnienie nieustannej

${ }_{63}$ M. Weber, Etyka gospodarcza..., s. 288.

64 Ibidem, s. 268-271; J. Love, op. cit., s. 208.

65 M. Weber, Etyka gospodarcza..., s. 278.

${ }^{66}$ Ibidem, s. 109.

67 Ibidem, s. 282. 
zasadności zemsty Jahwe, dostateczne umotywowanie i wyjaśnienie wszystkiego gniewem Boga ${ }^{68}$. W rozumieniu proroków Bóg był władcą postępującym w sposób zrozumiały dla człowieka, a ten pragnął wiedzieć, jak zdobyć jego łaskę. Prorocy nie stawiali pytań o sens przemijalności świata, czy życia o przyczynę kruchej, obciążonej winą i cierpieniem ludzkiej egzystencji. Nigdy nie skłaniała proroków ku Bogu potrzeba zbawienia czy doskonalenia indywidualnej ludzkiej duszy w obliczu niedoskonałego świata. Prorok nie czuł się zjednoczony z boskością (majestatyczna osobowość Boga-władcy wykluczała wszelką myśl o mistycznej unii z nim) i uwolniony od męki i bezsensu świata. Metafizyczna gnoza i interpretacja świata nie była brana pod uwagę, istota Jahwe nie zawierała bowiem niczego ponadzmysłowego, co leżało poza możliwościami rozumienia. Motywy Boga nie były niedostępne ludzkiej racjonalności, wręcz przeciwnie, właśnie rozumienie decyzji Jahwe, wynikających ze słusznych motywów, stanowiło zadanie proroków i nauczycieli Tory. Ten racjonalny charakter, zarówno wydarzeń zachodzących w świecie, którymi nie włada przypadek ani moce magiczne, lecz zrozumiałe przyczyny, jak i samego profetyzmu (proroctwa, w przeciwieństwie do gnostyckiej ezoteryki, pozostawały zrozumiałe dla każdego), był przez Żydów, także i później, uznany za specyficzną cechę ich proroków ${ }^{69}$. Przykazania Jahwe, podobnie jak jego dawne obietnice z czasów konfederacji, oraz prorockie nawoływania do ich przestrzegania cechowała konkretność i zorientowanie na doczesność. Odpowiedzi domagały się tylko aktualne problemy związane $\mathrm{z}$ aktywnością wewnątrzświatową, problemów teodycei nie podnoszono. Jak stwierdzał Weber, „by ocenić doniosłość tego stanu rzeczy, należy sobie uświadomić wynikającą z niego niesłychaną ekonomiczność gospodarowania siłami duchowymi"70. Religia żydowska rozważaniom nad istotą kosmosu postawiła trwałą barierę; szczęście człowieka nie wiązało się z poznaniem sensu świata, przynosiło mu je działanie zgodne z przykazaniami Boga. Codziennej etyce judaistycznej specyficznej jakości nie nadała wyjątkowość jej nakazów, etyka ta nie różniła się znacząco od etyk innych ludów, lecz leżąca u jej podstaw zasadnicza postawa religijna, na którą trudny do przecenienia wpływ wywarł profetyzm ${ }^{71}$. Zasługą tradycji profetycznej był monoteizm, stworzenie wizji uniwersalnego Boga etycznego, jedynego decydującego o losach świata. Prestiż religijności profetycznej zatriumfował w czasie niewoli babilońskiej, gdy sprawdziły się przepowiednie klęski i zniszczenia.

${ }_{68}$ Ibidem, s. 286-287. Z zasadą odpowiedzialności zbiorowej zerwało Deuteronomium. Profetyzm zorientowany na losy całego narodu, nie jednostki, w tym punkcie pozostał konserwatywny (ibidem, s. 286).

69 Ibidem, s. 284-285.

70 Ibidem, s. 287.

71 Ibidem, s. 288. 
Wniosek, że bóg babilońskiego króla Nabuchodonozora II (Marduk) pokonał Jahwe, mógł stać się wówczas oczywisty. Jednak zgodnie z religijnością wypracowaną przez proroków, dotychczasowe klęski narodu izraelskiego tłumaczono niewłaściwym postępowaniem, czynami pozostającymi w sprzeczności z postanowieniami zawartymi w przymierzu z Jahwe. Na wygnaniu babilońskim koncepcja ta ulega przekształceniu w kierunku mesjanistycznym. Według niej, Bóg ukarał odstępstwo Izraelitów, zsyłając Nabuchodonozora, który w jego ręku stał się narzędziem, mającym unaocznić Izraelitom ich dziejową misję w postaci głoszenia monoteizmu, wiary w jednego, panującego nad światem Boga (Iz 55:3-5, 10-11). Prorocka teodycea nieszczęścia swój punkt kulminacyjny znalazła na wygnaniu, gdzie Izrael ukazany został jako przedmiot zbawienia, cierpienie ludu stało się przedmiotem gloryfikacji i światowej misji historycznej.

Przemiana znaczenia przymierza dokonana za sprawą działalności proroków uczyniła z Żydów wspólnotę religijno-polityczną, różną, a przez to oddzieloną, od otaczającego ją środowiska, co przyczyniło się do rozwoju etyki, określanej przez Webera jako etyka negatywnie uprzywilejowanych, czyli etyka grup traktujących swe przykre położenie za niezasłużone i uznających się za predestynowane do zajęcia w przyszłości należnej im uprzywilejowanej pozycji. Weber podzielał, choć nie bezkrytycznie, przekonanie Friedricha W. Nietzschego, że „moralność bezsilnej nienawiści” ${ }^{72}$ była dziełem Żydów ${ }^{73}$. Nakazane przez Boga cnoty praktykowane są przez wzgląd na nadzieję odpłaty i jest to w pierwszym rzędzie nadzieja kolektywna: to naród jako całość doznać ma

72 „[...] na gruncie żydowskiej etycznej religijności zbawienia - pisał Weber - nabiera znaczenia pewien element, zauważony po raz pierwszy przez Nietzschego, nie występujący w żadnej magicznej i animistycznej religijności kastowej. Element ten to ressentiment. Jest to w rozumieniu Nietzschego zjawisko towarzyszące religijnej etyce negatywnie uprzywilejowanych, którzy dokonując bezpośredniego odwrócenia starej wiary sądzą, że źródłem nierówności losów ziemskich jest grzech i niesprawiedliwość pozytywnie uprzywilejowanych, grzech i niesprawiedliwość, które wcześniej czy później muszą sprowadzić pomstę Boga. W postaci takiej teodycei negatywnie uprzywilejowanych moralizm służy jako środek uprawomocnienia świadomego lub nieświadomego pragnienia zemsty" (M. Weber, Szkice z socjologii religii, Warszawa 1995, s. 182; zob. też: idem, Gospodarka i społeczeństwo..., s. 386).

73 Nietzsche uważał, że tego rodzaju moralność zrodziła kasta kapłańska, rywalizująca z kastą rycersko-arystokratyczną. Założeniem ocen rycersko-arystokratycznych jest cielesność i zdrowie oraz to, co służy ich podtrzymaniu, czyli wojna, polowanie, igrzyska i zabawa. Wartości kapłańskie pozostawały w opozycji do działania, skoncentrowane na niechęci do witalności i piękna cielesnego, pychy, rządzy panowania, czy bystrości (F. Nietzsche, Z genealogii moralności, Kraków 2011, s. 27). 
wywyższenia i przez to także jednostka może odzyskać swój honor ${ }^{74}$. Nadzieja zemsty dla pobożnych Żydów wiążąca się z moralizmem prawa, przenikająca niemal wszystkie święte pisma okresu niewoli babilońskiej i epoki późniejszej, w religijnej świadomości intelektualistów ustępowała co pewien czas zażyłości z Bogiem, wartości pobożnego zawierzenia boskiej dobroci i gotowości pogodzenia się ze światem. Działo się tak - uważał Weber - szczególnie w okresach względnie dobrego położenia skazanych na polityczną bezsilność gmin żydowskich. W okresach prześladowań podnoszono wołanie do Boga o zemstę albo modlono się o prawość własnej duszy w obliczu otaczającej wrogości. Choć - stwierdzał Weber - uznanie resentymentu za rozstrzygający element religijności żydowskiej, ulegającej na przestrzeni czasu istotnym zmianom, byłoby niewybaczalnym wypaczeniem, to jednak nie należy również lekceważyć jego wpływu na jej zasadnicze znamiona ${ }^{75}$.

Według Webera, profetyzm przyczynił się do przemiany wojowniczej wspólnoty wiary w Jahwe w religijną wspólnotę kultową po upadku państwowości, inaczej mówiąc do przemiany Izraelitów w Żydów. Transformacja ta uczyniła z Żydów „naród pariasów”76, którym stali się od niewoli babilońskiej, „naród gości” (Gastvolk), faktycznie lub formalnie oddzielony od świata zewnętrznego. Bez proroków i stworzonej przez nich teodycei cierpienia - twierdził Weber - Żydzi raczej nie zgodziliby się na ten status. Według socjologa, od pariasów indyjskich różnili się zasadniczo trzema ważnymi okolicznościami. Po pierwsze, stali się ludem pariasów w środowisku pozbawionym kast. Po drugie, obietnica zbawienia, w której pozostawała zakotwiczona rytualna odrębność judaizmu, miała zupełnie inny charakter niż u kast indyjskich. $\mathrm{U}$ tych ostatnich nagrodą za poprawne rytualnie zachowanie było wspięcie się, poprzez ponowne narodziny, na wyższy poziom, traktowanego jako wieczny, kastowego porządku świata. Utrzymanie porządku kastowego w niezmienionej formie było warunkiem wstępnym wszelkiego zbawienia, co wiązało się z traktowaniem świata jako bytu wiecznego i ahistorycznego. U Żydów obietnica zbawienia miała dokładnie odwrotny charakter: uważano, że porządek świata obrócił się był w przeciwieństwo tego, co zostało obiecane na przyszłość i w przyszłości miał zostać odwrócony tak, że narodowi żydowskiemu znów przypadłaby, przypisana mu, pozycja narodu wybranego. Świat nie był ani wieczny, ani niezmienny, lecz stworzony. Jego współczesny porządek stanowił efekt działania ludzi, przede wszystkim Żydów i reakcji ich Boga na to działanie, czyli był wytworem historycznym, którego przeznaczenie zawierało się

\footnotetext{
74 M. Weber, Gospodarka i społeczeństwo..., s. 387.

75 Ibidem, s. 387.

${ }^{76}$ M. Weber, Etyka gospodarcza..., s. 11; idem, Gospodarka i społeczeństwo..., s. 384-385.
} 
w ustąpieniu miejsca stanowi pożądanemu przez Boga. Weber uważał, że cały stosunek starożytnych Żydów do życia wyznaczało to wyobrażenie, prowadzonej pod przewodnictwem Boga, przyszłej rewolucji politycznej i społecznej. I po trzecie, poprawność rytualna i uwarunkowana przez nią izolacja od środowiska społecznego stanowiły jedną stronę przyjętych przez Żydów nakazów. Stronę drugą reprezentowała wysoce racjonalna, to znaczy wolna od magii i irracjonalnych form poszukiwania zbawienia, religijna etyka wewnątrzświatowego działania ${ }^{77}$. Etyka ta rozwinięta została następnie przez protestantyzm reformowany.

Źródło zmian w religijności żydowskiej, prowadzących w kierunku zracjonalizowanej etyki, tkwić miało nie tylko w społecznym położeniu negatywnie uprzywilejowanych. Nośnik racjonalnej, etycznej pobożności stanowił też sposób życia drobnomieszczaństwa, stanowiącego fundament religijności gminy. Warstwa rzemieślników i drobnych kupców, z racji swego sposobu życia, wszędzie tam gdzie istniały ku temu warunki, skłaniała się ku etycznej, racjonalnej religijności. Ich życie pozostawało powiązane $\mathrm{z}$ naturą $\mathrm{w}$ znacznie mniejszym stopniu niż egzystencja chłopów, zależność od irracjonalnego oddziaływania na duchy natury w przypadku drobnomieszczan nie miała takiego samego znaczenia. Ich warunki bytu cechował zasadniczo bardziej racjonalny charakter, poddawały się one kalkulacji i celowo racjonalnym wpływom. Tym samym sposób życia rzemieślników i drobnych kupców przyczyniał się aktywnie do rugowania magii; rzetelna praca, spełnianie obowiązków, uczciwość, dotrzymywanie słowa leżały w ich własnym interesie, znajdywały doczesną nagrodę, której były warte. Stanowiło to etyczne, racjonalne ujęcie rzeczywistości w znaczeniu etyki odpłaty, bliskiej wszystkim nieuprzywilejowanym warstwom. Natomiast warstwy wojowników, zainteresowanych ekonomicznie wojną i rozwojem władzy politycznej, pozostawały mało wrażliwe na etycznie racjonalne elementy religijności ${ }^{78}$.

Losy religii żydowskiej determinował również intelektualizm, zwłaszcza metafizyczne potrzeby indywidualnego ducha, którego ku rozważaniom etycznym i religijnym nie zmuszała niedola materialna, lecz przymus wewnętrzny, by móc ująć świat jako sensowny kosmos i zająć wobec niego stanowisko. Początkowo nośnikami intelektualizmu w religii żydowskiej byli kapłani i prorocy, którzy stworzyli fundamenty judaizmu. Intelektualiści szukali zbawienia od wewnętrznej niedoli, dlatego ich wizja zbawienia z jednej strony pozostawała bardziej oddalona od świata, a z drugiej - miała bardziej usystematyzowany charakter niż zbawienie od niedoli zewnętrznej, charakterystyczne dla warstw

M. Weber, Etyka gospodarcza..., s. 11-12.

78 M. Weber, Gospodarka i społeczeństwo..., s. 376-377. 
nieuprzywilejowanych. Intelektualista starał się nadać swojemu sposobowi życia całościowy sens, a zatem doprowadzić do jedności z sobą samym, z ludźmi i z kosmosem. Problem sensu świata zaistniał właśnie w ujęciu intelektualnym. Intelektualizm wypierał wiarę $\mathrm{w}$ magię i tym samym odczarowywał procesy w świecie, które traciły swój magiczny sens, już tylko „były” i „działy się," lecz przestawały cokolwiek znaczyć. W związku z tym pilny stawał się wymóg, by świat i sposób życia jako całości znamionowały znaczenie i sens. Ten filozoficzny intelektualizm, którego nośnikami były zazwyczaj dobrze sytuowane warstwy społeczeństwa, pozostawał w związku z ,intelektualizmem proletaroidalnym", jak określał go Weber, reprezentowanym przez biednych, dysponujących podrzędnym wykształceniem, drobnych urzędników i beneficjentów, nienależących do uprzywilejowanych warstw biegłych w sztuce pisania (w czasach, gdy pisanie uchodziło za odrębny zawód) nauczycieli wiedzy elementarnej, wędrownych śpiewaków, lektorów, opowiadaczy. Wśród Żydów, jak u żadnego innego narodu, ten drobnomieszczański ,intelektualizm pariasów” był bardzo rozpowszechniony. Wyrażał się w krzewieniu umiejętności pisania i systematycznym kształceniu w kazuistycznym myśleniu przez szkoły uczonych w Piśmie. Za sprawą wpływu tej „plebejskiej” warstwy intelektualistów działalność proroków zastąpiona została wśród żydowskiego mieszczaństwa kultem wierności Prawu ${ }^{79}$.

Jak zauważał Weber, „intelektualizm pariasów” charakterystyczny był także dla sekt protestanckich, stając się dla nich źródłem niezwykłej siły oporu. W XVII wieku kręgi purytańskie charakteryzowało upowszechnienie znajomości Biblii oraz zainteresowania, zawiłymi niekiedy i subtelnymi, dogmatycznymi kontrowersjami, nawet wśród chłopów. Stworzyło ono religijny intelektualizm masowy, który później nie znalazł już swego odpowiednika. W przeszłości natomiast można go porównać jedynie do fenomenu wspomnianego religijnego intelektualizmu masowego późnego judaizmu i Pawłowych gmin misyjnych ${ }^{80}$.

W kreacji etyki racjonalnej, głównego osiągnięcia starożytnego judaizmu, przymierze miało znaczenie kluczowe. Do jej rozwoju przyczyniły się działalność proroków oraz drobnomieszczański sposób życia i plebejski intelektualizm w okresie późnego judaizmu. W przekonaniu Webera etyka ta miała trudny do przecenienia wpływ na kształt nowoczesnego oblicza Zachodu. Z powodu śmierci Webera proces związków tej etyki z kulturą zachodnią nie został wykazany, chociaż było to jego zamiarem. Wedle planów, kontynuacją Starożytnego judaizmu miała być praca poświęcona judaizmowi talmudycznemu

\footnotetext{
79 Ibidem, s. 389-390, 394, 396.
}

80 Ibidem, s. 400. 
oraz początkom zachodniego chrześcijaństwa, w których proces racjonalizacji poddany zostałby dalszej analizie. To, że tak się nie stało, jest ogromną naukową stratą. Od Webera wiemy, że ducha racjonalnej etyki judaizmu odkrył na nowo protestantyzm reformowany, że nawiązał do jej zasadniczego dążenia uczynienia życia człowieka w świecie jak najbardziej zbliżonym do oczekiwań Boga, wyrażonych w zawartym z Nim przymierzu ${ }^{81}$. U protestantów reformowanych pojęcie przymierza, do którego na gruncie teologii katolickiej nie przywiązywano wagi, ponownie nabrało znaczenia nie tylko religijnego, ale także politycznego.

\section{Podsumowanie}

W interpretacji Maxa Webera, przymierze stanowiło instrument polityczny Izraelitów, który w epoce proroków stał się katalizatorem sprzyjającym procesowi racjonalizacji i etyzacji religii żydowskiej. Proces ten był zatem konsekwencją rozwoju świadomości politycznej Izraelitów, wyrażającej się $\mathrm{w}$ postaci przymierza $\mathrm{z}$ Jahwe, mającego charakter obronny w odniesieniu do związku plemiennego oraz społeczno-polityczny, jeśli chodzi o relacje wewnątrzplemienne. Analiza Webera dowodzi, że, podobnie jak miało to miejsce w przypadku greckiej filozofii politycznej, z której wzięła swój początek etyka, także u Żydów etyka, w tym wypadku religijna, pozostawała w związku z polityką - rozwinęła się jako konsekwencja praktycznych doświadczeń politycznych Izraelitów. Również w przypadku Żydów polityka może zostać zatem potraktowana jako podmiot etyzujący. Jahwe, Bóg natury, stał się z czasem Bogiem plemiennej organizacji politycznej, by za sprawą ruchu profetycznego zyskać status Boga etycznego. Etyka pozostawała ściśle związana z przestrzeganiem norm prawnych, będących przedmiotem przymierza politycznego. Jahwe rozumiany był jako Bóg zainteresowany ludzką doczesnością, Bóg współpracujący z Izraelitami w oparciu o zasady przymierza, działający w świecie Bóg polityczny, zaangażowany w los konkretnego narodu.

\section{Bibliografia}

Bendix R., Max Weber. Portret uczonego, Warszawa 1975.

Grant M., Dzieje dawnego Izraela, Warszawa 1991, s. 35-40, http://www.opracowanie.eu/grant.htm [dostęp: 9.08.2013].

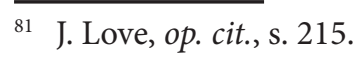


Hefner A.G., Baal, Encyclopedia Mythica from Encyclopedia Mythica Online, http://www.pantheon.org/articles/b/baal.html [dostęp: 9.08.2013].

Love J., Max Weber's Ancient Judaism, [w:] The Cambridge Companion to Weber, S.P. Turner (red.), Cambridge 2000, s. 200-220.

Mittleman A., Max Weber's Conception of Covenant in Ancient Judaism, with Reference to the Book of Judges, "Jewish Political Studies Review” 1994, no 1-2, s. 9-25.

Nicholson E.W., God and His People. Covenant and Theology in the Old Testament, Clarendon Press, Oxford 1986.

Nietzsche F., Z genealogii moralności, Kraków 2011.

Robertson Smith W., Preface, [w:] Prolegomena to the History of Ancient Israel, J. Wellhausen (red.), Cleveland 1957, s. 1-16.

Weber M., Etyka gospodarcza religii światowych, t. 3: Starożytny judaizm, Kraków 2000.

Weber M., Gospodarka i społeczeństwo. Zarys socjologii rozumiejącej, Warszawa 2002.

Weber M., Szkice z socjologii religii, Warszawa 1995.

Wellhausen J., Prolegomena to the History of Ancient Israel, Cleveland 1957.

\begin{abstract}
In Max Weber's interpretation, the covenant was a political instrument of the Israelites. In Weber's view, the original goal of the Sinai covenant was the political goal - strengthening the defense force of scattered Israeli tribes, and within the tribes it gave the durability of socio-economic relations between social groups, mainly between shepherds of small herds and a farmers or a city military patriciate owning land. The covenant had a defensive character with regard to the tribal union and socio-political character in terms of intertribal relations. Israel was developing and gaining its specific character as a cult and military union based on free shepherds and farmers, uniting during the wars against enemies. In the later age of prophets, the covenant became a catalyst for the process of rationalizing and ethicizing the Jewish religion. This process was, therefore, a consequence of the development of the political consciousness of the Israelites, expressed in the form of the covenant with Yahweh.
\end{abstract}

Keywords: covenant, Israel, Yahweh, tribal union, ethics, rationalization 